Paul D. Try

Ching-Yen Tsay

Paul F. Twitchell

Louis W. Uccellini

Martin A. Uman

William W. Vaughan

Donald L. Veal

Joseph Vederman

Anandu D. Vernekar

Dayton G. Vincent

Harry A. Volkman

William S. von Arx*

Thomas H. Vonder Haar

Bernard Vonnegut*

Valerie Voss
Paul E. Waggoner

Richard A. Wagoner

Roger M. Wakimoto

John E. Wallace*

John M. Wallace

John E. Walsh, Jr.

David Q. Wark

Warren M. Washington

Peter John Webster

Helmut K. Weickmann*

James A. Weinman

Fred D. White*

Robert M. White

Aksel C. Wiin-Nielsen

Thomas T. Wilheit
Robert B. Wilhelmson

Hurd C. Willett*

Gareth P. Williams

Philip Williams, Jr.*

Roger Terry Williams

David L. Williamson

Hugh Edward Willoughby

John W. Wilson

Larry F. Wilson

Jay S. Winston

George A. Winterling

Warren J. Wiscombe

Paul M. Wolff

Eric F. Wood
Alfred H. Woodcock**

Warren S. Wooster

Oliver R. Wulf*

Carl Wunsch

Morton G. Wurtele

John C. Wyngaard

Klaus Wyrtki

Michio Yanai

Donald N. Yates*

John A. Young

Susan F. Zevin

John W. Zillman

Edward J. Zipser

Dušan S. Zrnić

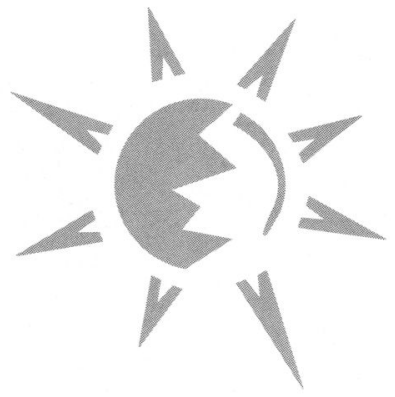

\title{
Contributions and Bequests to the Society
}

Since its establishment in 1919, the American Meteorological Society has benefited from the generosity of individuals and firms who have made contributions and bequests to the Society.

Resources have been made available for scholarships, for awards in recognition of outstanding contributions to the atmospheric and related sciences, and for general support of the Society's scientific and educational programs. Some scholarships and awards have taken the form of memorials of deceased members.

The Society encourages gifts and bequests. Donors may designate the purpose for which a contribution is made, subject to the approval of the Council.
There are several ways of giving to the Society. The most frequent and simple way is a direct gift of cash or securities. A donor wishing to make a bequest is encouraged to consult an attorney. Gifts to the Society are deductible for the purpose of calculating income and estate taxes to the extent provided in those laws for gifts and bequests to tax-exempt organizations.

Inquiries concerning contributions and bequests should be directed to: Richard E. Hallgren, Executive Director, AMS, 45 Beacon St., Boston, MA 02108-3693. 